NASA/TM-2005-213806

\title{
Hydrodynamics of Packed Bed Reactor in Low Gravity
}

Brian J. Motil and Henry K. Nahra

Glenn Research Center, Cleveland, Ohio

Vemuri Balakotaiah

University of Houston, Houston, Texas 
Since its founding, NASA has been dedicated to the advancement of aeronautics and space science. The NASA Scientific and Technical Information (STI) Program Office plays a key part in helping NASA maintain this important role.

The NASA STI Program Office is operated by Langley Research Center, the Lead Center for NASA's scientific and technical information. The NASA STI Program Office provides access to the NASA STI Database, the largest collection of aeronautical and space science STI in the world. The Program Office is also NASA's institutional mechanism for disseminating the results of its research and development activities. These results are published by NASA in the NASA STI Report Series, which includes the following report types:

- $\quad$ TECHNICAL PUBLICATION. Reports of completed research or a major significant phase of research that present the results of NASA programs and include extensive data or theoretical analysis. Includes compilations of significant scientific and technical data and information deemed to be of continuing reference value. NASA's counterpart of peerreviewed formal professional papers but has less stringent limitations on manuscript length and extent of graphic presentations.

- TECHNICAL MEMORANDUM. Scientific and technical findings that are preliminary or of specialized interest, e.g., quick release reports, working papers, and bibliographies that contain minimal annotation. Does not contain extensive analysis.

- CONTRACTOR REPORT. Scientific and technical findings by NASA-sponsored contractors and grantees.
- CONFERENCE PUBLICATION. Collected papers from scientific and technical conferences, symposia, seminars, or other meetings sponsored or cosponsored by NASA.

- SPECIAL PUBLICATION. Scientific, technical, or historical information from NASA programs, projects, and missions, often concerned with subjects having substantial public interest.

- TECHNICAL TRANSLATION. Englishlanguage translations of foreign scientific and technical material pertinent to NASA's mission.

Specialized services that complement the STI Program Office's diverse offerings include creating custom thesauri, building customized databases, organizing and publishing research results ... even providing videos.

For more information about the NASA STI Program Office, see the following:

- Access the NASA STI Program Home Page at http://www.sti.nasa.gov

- E-mail your question via the Internet to help@sti.nasa.gov

- Fax your question to the NASA Access Help Desk at 301-621-0134

- Telephone the NASA Access Help Desk at 301-621-0390

- Write to:

NASA Access Help Desk

NASA Center for AeroSpace Information 7121 Standard Drive

Hanover, MD 21076 
NASA/TM-2005-213806

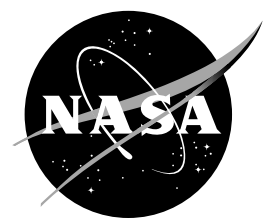

\section{Hydrodynamics of Packed Bed Reactor in Low Gravity}

Brian J. Motil and Henry K. Nahra

Glenn Research Center, Cleveland, Ohio

Vemuri Balakotaiah

University of Houston, Houston, Texas

Prepared for the

35th International Conference on Environmental Systems (ICES)

cosponsored by the SAE, AIAA, AIChE, ASME, and the

International ICES Committee

Rome, Italy, July 11-14, 2005

National Aeronautics and

Space Administration

Glenn Research Center 
Trade names or manufacturers' names are used in this report for identification only. This usage does not constitute an official endorsement, either expressed or implied, by the National Aeronautics and Space Administration.

Available from

NASA Center for Aerospace Information 7121 Standard Drive

Hanover, MD 21076
National Technical Information Service 5285 Port Royal Road Springfield, VA 22100

Available electronically at http:/ /gltrs.grc.nasa.gov 


\title{
Hydrodynamics of Packed Bed Reactor in Low Gravity
}

\author{
Brian J. Motil and Henry K. Nahra \\ National Aeronautics and Space Administration \\ Glenn Research Center \\ Cleveland, Ohio 44135 \\ Vemuri Balakotaiah \\ University of Houston \\ Houston, Texas 77002
}

\begin{abstract}
Packed bed reactors are well known for their vast and diverse applications in the chemical industry; from gas absorption, to stripping, to catalytic conversion. Use of this type of reactor in terrestrial applications has been rather extensive because of its simplicity and relative ease of operation. Developing similar reactors for use in microgravity is critical to many space-based advanced life support systems. However, the hydrodynamics of two-phase flow packed bed reactors in this new environment and the effects of one physiochemical process on another has not been adequately assessed. Surface tension or capillary forces play a much greater role which results in a shifting in flow regime transitions and pressure drop. Results from low gravity experiments related to flow regimes and two-phase pressure drop models are presented in this paper along with a description of plans for a flight experiment on the International Space Station (ISS). Understanding the packed bed hydrodynamics and its effects on mass transfer processes in microgravity is crucial for the design of packed bed chemical or biological reactors to be used for water reclamation and other life support processes involving water purification.
\end{abstract}

\section{Introduction}

The typical operation of a packed bed reactor (PBR) involves the simultaneous liquid and gas flow that on ground can be co-current or counter-current. The packing can be of different shape and materials depending on the application. For chemical reactions, the packing usually serves as a catalyst. For biological reactions, the packing can serve as a structural support for biofilm growth. For physical processes such as absorption or leaching, the packing provides for gas-liquid phase interaction and extended contact in order to achieve the highest mass transfer rates.

The results of a recent reduced gravity aircraft experiment will be compared in this paper to a previously published microgravity model. The model predicts flow regime transitions and pressure drop for spherical packing. The model was initially validated with a small scale rectangular column and glass beads. The latest set of flights involved a realisticscale cylindrical bed with a common packing material (aluminum oxide spheres). The results will be compared in a preliminary fashion in order to expand the validation of the model to a different bed geometry and packing material. A critical validation still remains for flows that require longer time scales ( $>20$ seconds) than are available on the aircraft.

Testing the PBRE within a long duration microgravity environment is the next critical step to validating the hydrodynamic models and this will be addressed by a planned ISS flight experiment. The fully validated models will enable designers to predict reactor bed performance in space (transit missions) directly or establish a " 0 -g boundary condition" to develop the predictive framework for planetary operations (moon or Mars).

\section{Experiments on NASA's Low Gravity Facility}

\section{Experimental System}

A simplified flow schematic of the experimental apparatus is illustrated in figure 1. The experiment was designed to fly on NASA's low gravity aircraft, which is capable of flying parabolic trajectories to create a reduced-gravity environment for approximately 20 seconds. Acceleration levels were recorded in three mutually orthogonal axes (one coinciding with the direction of flow) and typically averaged less than $0.01 \mathrm{~m} / \mathrm{s}^{2}$ during the 20-second "low-g" period. Gas was provided to the test section by a compressed air cylinder and was controlled by regulating the pressure upstream of an orifice. Two different sized orifices were selected to maintain choked flow conditions for all flow rates and were verified with a mass flow meter before each test day. Liquid flow was maintained by applying air pressure to a piston, which in turn forced the liquid through a meter and into the test section. A pressure-driven piston, rather than a pump, is necessary during low gravity to ensure steady liquid flow. The two phases were mixed prior to the test section and then introduced into the column through a coarse mesh screen. To maintain a steady pressure at the outlet of the test section, a two-phase 


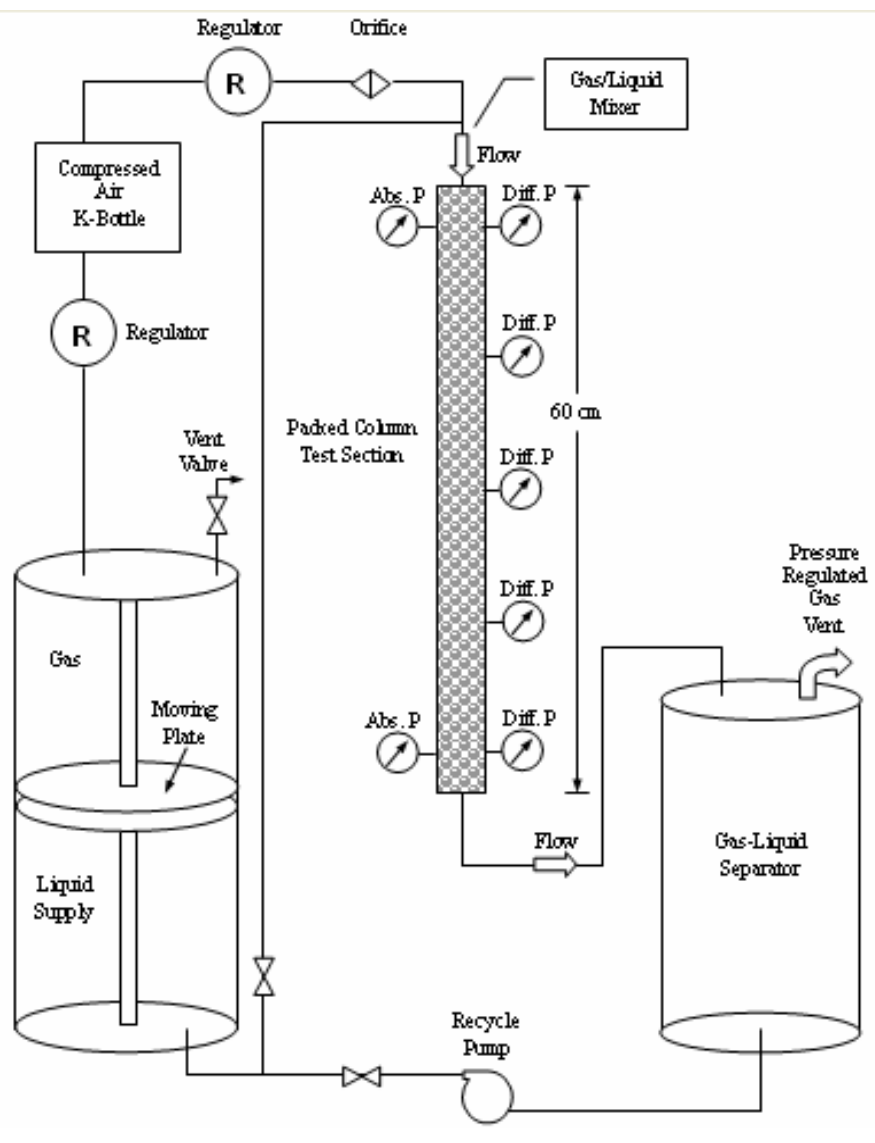

Figure 1.-Schematic of the aircraft flow loop.

separator/collector tank was used to retain the liquid phase while venting the gas (air) to the cabin via a back-pressure regulator. Average pressures within the packed bed test section were held between 100 to $200 \mathrm{kPa}$. Between trajectories, the liquid was pumped back to the supply tank.

First campaign.-Two test sections were flown in two separate campaigns on board of the two phase flow rig. In the first campaign, a clear rectangular polycarbonate column with a cross section of $2.54 \mathrm{~cm}$ by $5.08 \mathrm{~cm}$ and $60 \mathrm{~cm}$ long was used for the test section. The fluid viscosity was varied between $1-20 \mathrm{cP}$, the surface tension from 60 to 72 dynes $/ \mathrm{cm}$, and the liquid density from 1 to $1.2 \mathrm{~g} / \mathrm{cm}^{3}$. Spherical glass packing was used in the column. Two packing diameters of 2 and $5 \mathrm{~mm}$ were tested in the first campaign. Five flushmounted differential pressure transducers were spaced at even intervals with the first location approximately $4 \mathrm{~cm}$ from the inlet port and the subsequent pressure transducers spaced at $13 \mathrm{~cm}$ intervals along the column. In addition, absolute pressure transducers were located at the first and last positions. To observe pulse formation and characteristics adequately, the data from the differential pressure transducers were acquired at $1000 \mathrm{~Hz}$. Flow rates, temperatures, and absolute pressures were recorded at $1 \mathrm{~Hz}$. Visual observations were recorded using a high-speed SVHS video system at 500 frames per second. The column was randomly packed with spherical glass beads of identical diameter by slowly dropping the beads into the top of the bed. Handling and shaking the bed was kept to a minimum prior to the aircraft flights, but the vibration and alternating 0 to $1.8 \mathrm{~g}$ environment created a more tightly packed bed. The void fraction was measured by comparing the dry weight to the weight of the bed filled with water (recorded after the flight). Typically, the beads settled after only several parabolas leaving a gap of about 2 to $3 \mathrm{~cm}$ on the top of the column. The average void fraction was found to be 0.345 . As expected, this was slightly lower than the normal range of 0.36 to 0.43 reported in Kaviany (1995), but is consistent with the findings of Tosun (1984).

Second campaign.- In the second campaign, the geometry of the packed bed changed in addition to changing the packing materials. The column geometry in the second flight was cylindrical, with $7.62 \mathrm{~cm}(3 \mathrm{in}$.) diameter and $91.4 \mathrm{~cm}$ (36 in.) length. The first pressure transducer was $12.7 \mathrm{~cm}(5 \mathrm{in}$.) from the column inlet and the subsequent transducers were separated $19.1 \mathrm{~cm}(7.5 \mathrm{in}$.) from each other. The materials of the tested packing were glass and alumina (aluminum oxide), with the packing having the same diameter of $3 \mathrm{~mm}$. The liquid properties were constant since only water was used in the column. Bed settling due to acceleration changes was nearly similar for the circular column. The data acquisition system was similar to the first flight as well as the high-speed camera. Table 1 compares the two low gravity experiments. Figure 2 shows the hardware flown on NASA's low gravity platform.

TABLE 1.-RANGE OF PARAMETERS BETWEEN THE TWO EXPERIMENTS CONDUCTED ON THE NASA'S LOW GRAVITY PLATFORM.

\begin{tabular}{|c|c|c|}
\hline & $\begin{array}{c}\text { First } \\
\text { campaign }\end{array}$ & $\begin{array}{l}\text { Second } \\
\text { campaign }\end{array}$ \\
\hline Parameter & \multicolumn{2}{|c|}{ Range } \\
\hline Liquid Density $\rho_{L}$ & 1000 to $1200 \mathrm{~kg} / \mathrm{m}^{3}$ & $1000 \mathrm{~kg} / \mathrm{m}^{3}$ \\
\hline Gas Density $\rho_{G}$ & 0.95 to $2.3 \mathrm{~kg} / \mathrm{m}^{3}$ & 0.95 to $1.4 \mathrm{~kg} / \mathrm{m}^{3}$ \\
\hline Liquid Viscosity $\mu_{L}$ & 0.001 to $0.02 \mathrm{~kg} / \mathrm{m} \mathrm{s}$ & $0.001 \mathrm{~kg} / \mathrm{m} \mathrm{s}$ \\
\hline Gas Viscosity $\mu_{G}$ & $1.8 \times 10^{-5} \mathrm{~kg} / \mathrm{m} \mathrm{s}$ & $1.8 \times 10^{-5} \mathrm{~kg} / \mathrm{m} \mathrm{s}$ \\
\hline Liquid Surface Tension $\sigma_{L}$ & 0.060 to $.072 \mathrm{~kg} / \mathrm{s}^{2}$ & $0.070 \mathrm{~kg} / \mathrm{s}^{2}$ \\
\hline Packing Diameter $d_{P}$ & 0.002 and $0.005 \mathrm{~m}$ & $0.0035 \mathrm{~m}$ \\
\hline Packing Materials & $\begin{array}{c}\text { Glass } \\
\text { (spherical beads) }\end{array}$ & $\begin{array}{l}\text { Aluminum oxide } \\
\text { (semi-spherical) }\end{array}$ \\
\hline Bed Porosity $\varepsilon$ & 0.34 & 0.35 \\
\hline
\end{tabular}




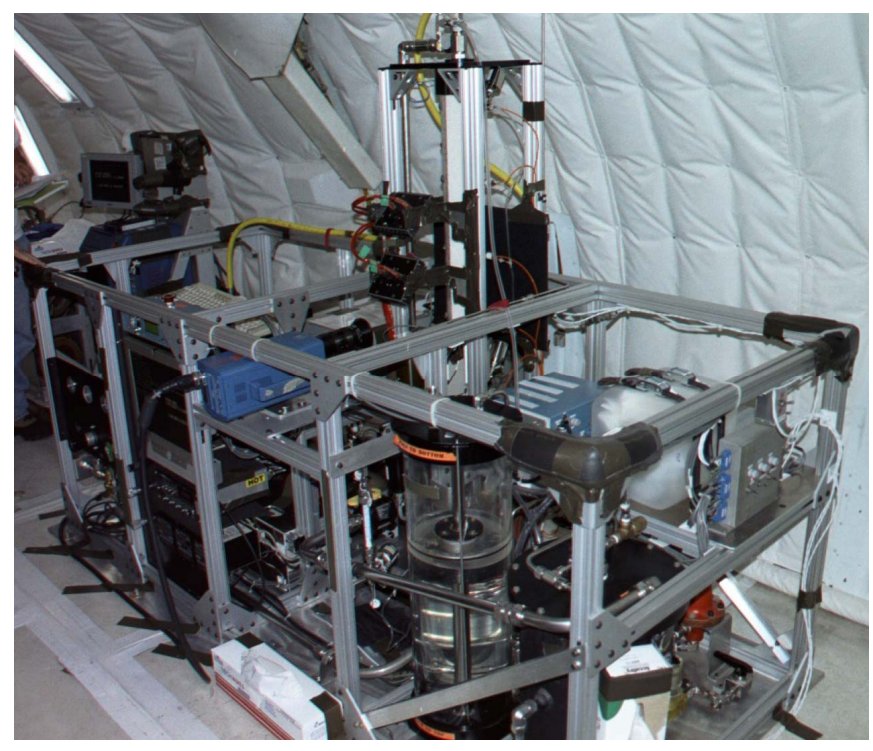

Figure 2.- Photograph of the two-phase aircraft rig.

\section{Hydrodynamic Model}

\section{Pressure Drop}

Pressure drop is an important parameter in designing a gasliquid reactor bed. Not only does it affect the energy required to operate the bed, but it is often used to correlate the mass transfer from either the gas to liquid or the liquid to solid phases (Reiss, 1967; Gianetto et al., 1978).

In the literature, pressure drop models based on superimposing the kinetic and viscous energy losses (Erguntype equations) have worked reasonably well for gas-liquid flows by restricting use to the gas-continuous trickle flow regimes and neglecting the effects of gravity and interactions between the gas and liquid phases. In the absence of gravity, the surface tension forces become increasingly dominant as the liquid flow rates are decreased. Furthermore, neglecting gravity effects are justified even for the liquid-continuous bubbly and pulse regimes. Motil et al., 2003 extended this approach for microgravity by superimposing an additional "dynamic interaction" term resulting in:

$$
\begin{aligned}
f_{T P} & =\frac{-\Delta P}{Z} \frac{d_{P}}{\rho_{L} U_{L S}^{2}} \frac{\varepsilon^{3}}{1-\varepsilon} \\
& =\frac{1}{\operatorname{Re}_{L S}^{*}}[150+\underbrace{0.8\left(\operatorname{Re}_{G S}^{*}\right)^{\frac{1}{2}}\left(\frac{\left.S u_{L}\right)^{\frac{2}{3}}}{\operatorname{Re}_{L S}^{*}}\right)^{3}}_{\text {Dynamics Interaction }}]+1.75
\end{aligned}
$$

where

$$
\frac{1}{W e_{L S}^{*}}=\frac{S u_{L}}{\left(\operatorname{Re}_{L S}^{*}\right)^{2}}, S u_{L}=\frac{\rho_{L} d_{p} \sigma}{\mu_{L}^{2}}
$$

The dynamic phase interaction term is indicated in equation (1). In the limit of zero interfacial tension between fluids $(\sigma \approx 0)$, it reduces to the single phase Ergun equation (dynamic interaction term goes to zero) and in the limit of no gas flow $\left(\operatorname{Re}_{G S}^{*}=0\right)$, it again reduces to the single phase Ergun equation. In the inertia dominated limit $\left(\operatorname{Re}_{L S}^{*}>>1\right)$, the friction factor becomes independent of the interfacial tension and viscous terms and approaches the same asymptotic solution as the inertia dominated single phase solution.

Sample plots of equation (1) are shown in figure 3 for two different Suratman numbers. The data points were generated from the first aircraft flight campaign. The Suratman number was varied by changing the packing size and liquid viscosity. Agreement is good for all flow ranges including pulse and bubbly flow. The scatter is small compared to other existing correlations for normal gravity two-phase pressure drop.

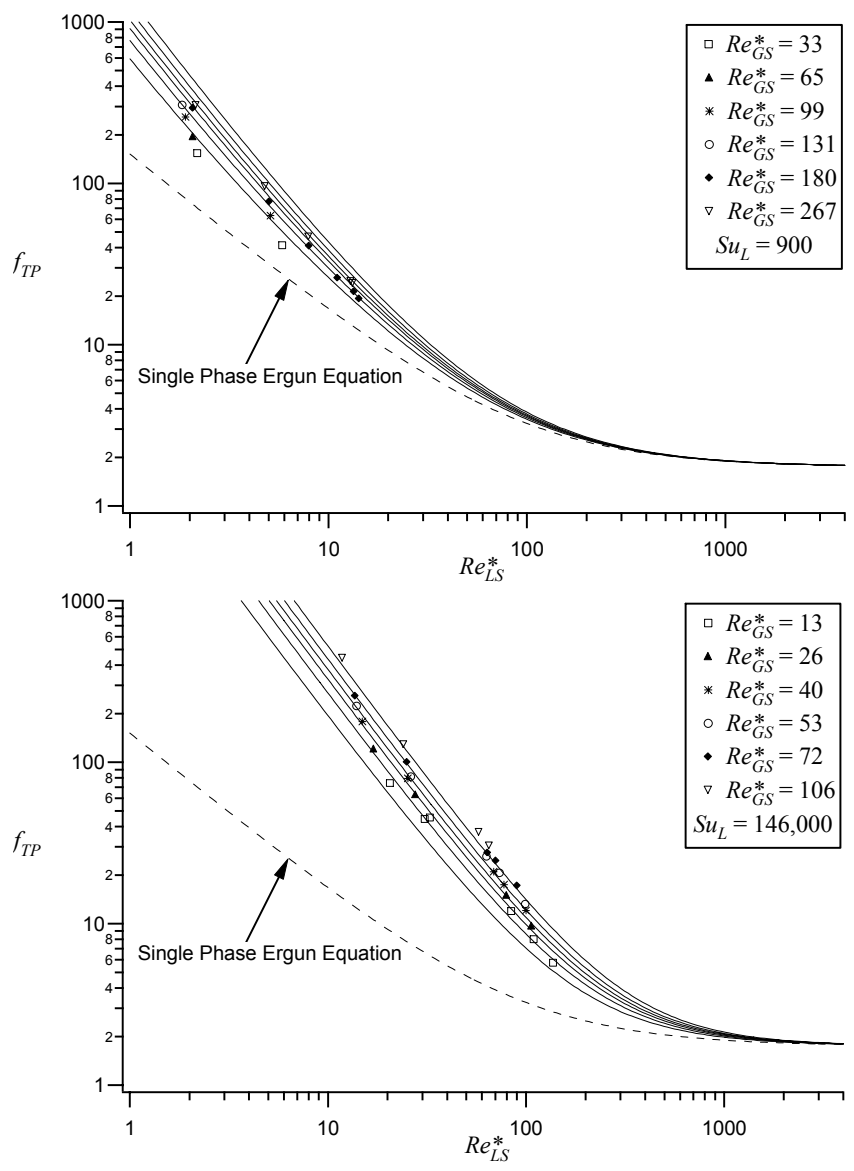

Figure 3.-Experimental validation of pressure drop in microgravity. 
In these experiments, pressure drop increases as the square root of the gas Reynolds number (or essentially the gas flow rate). This relationship holds reasonably well over the wide range of liquid velocities and viscosities. Figure 4 is a qualitative illustration of the effects of gas and liquid flow rates on the pressure drop. The lowest curve represents the Ergun equation for the single (liquid) phase where the viscous regime obeys the Darcy relationship $\Delta P \sim U_{L S}$. As the liquid flow is increased there is a "transition region" and then, at very high liquid flow rates, the Burke-Plummer (inertia regime) relationship $\triangle P \sim U_{L S}^{2}$ dominates. The effect of increasing the gas flow increases the pressure drop by the dynamic interaction relationship $\Delta P \sim U_{G S}^{1 / 2}+U_{L S}^{1 / 3}$. This term dominates the pressure drop at the lower liquid flow rates, but also becomes negligible along with the viscous term as the liquid flow rate is increased into the liquid inertia regime.

\section{Preliminary Scaling}

As mentioned earlier, one of the objectives of the second flight campaign was to validate the pressure drop model using a more realistic packing (semi-spherical alumina) and a bed scaled to the size of an expected biological or chemical reactor unit. The model showed excellent agreement with the experimental two-phase friction factor as illustrated in the parity plot in figure 5 .

\section{Future Plans for a Flight Experiment}

\section{Justification}

NASA considers packed bed technology as a unit operation for several advanced life support systems. Examples of packed bed reactors include the Volatile Removal Assembly (VRA), the Biological Water Processor (BWP), and the Sabatier Reactor. NASA is currently developing air and water systems with reactor beds for ground and flight-based testing without a fundamental understanding of how the reduced gravity environment affects the performance and reliability of the reactors. This is especially critical when gas and liquid flows are involved. The expected outcome of this research effort is to develop a set of guidelines and tools to enable engineers to reliably design and operate fixed packed bed reactors for microgravity as well as the lunar and Martian environments.

The flight experiment will provide critical hydrodynamic information for a project with a broader scope, which includes reduced gravity aircraft and ground-based (1-g) experiments. The main objective of the overall project is to develop and validate macroscopic equations that can be used in partial and microgravity conditions to accurately predict flow pattern transitions; pressure drops; and chemical and biological

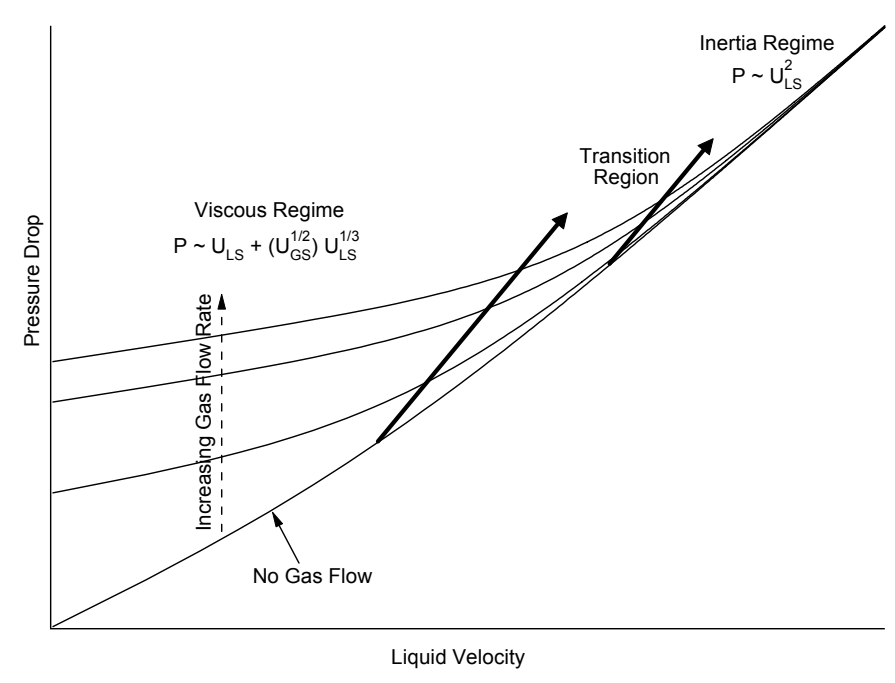

Figure 4.- Qualitative effect of gas flow rate on pressure drop.

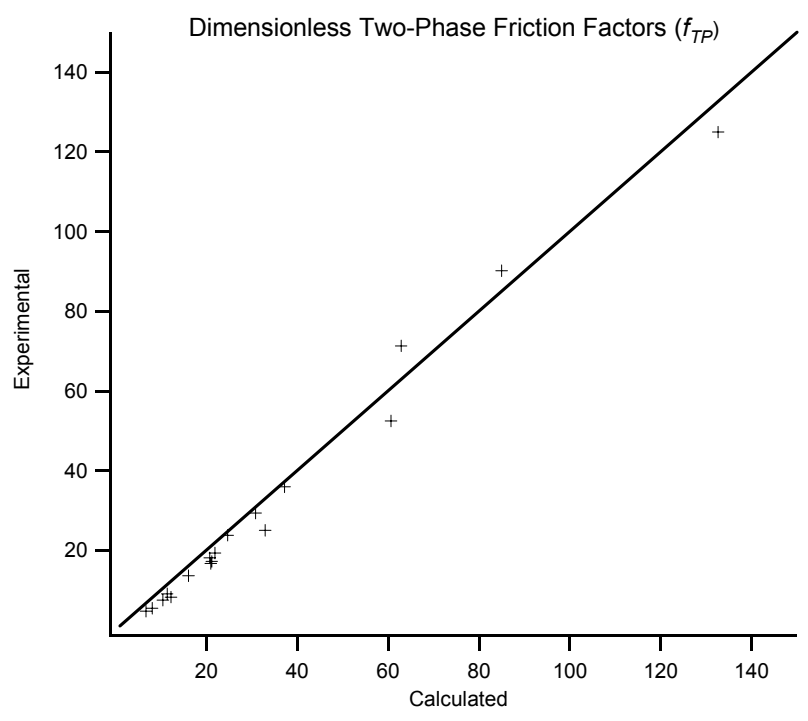

Figure 5.-Comparison plot for second flight campaign.

transport rates in gas-liquid flows through randomly packed beds. The hydrodynamic investigations discussed in this document will focus on the transitions between flow regimes (i.e., bubbly-to-pulse flow) and the associated pressure gradients for each flow regime over the range of relevant test parameters (e.g., liquid flow rates, gas flow rates, and particle sizes). These design tools will provide important information for specific water reclamation and air revitalization technologies in NASA's Advanced Life Support (ALS) program. 
There are several approaches to predicting the reaction rates (mass transfer) of a fixed PBR, but all are based on liquid (or gas) holdup within the reactor. Initial microgravity tests conducted in the reduced gravity aircraft and drop tower clearly show that the liquid holdup is significantly influenced by gravity (Motil et al., 2003). Furthermore, most of these models have only been verified using the trickle flow regime (not found in microgravity). Basic hydrodynamic models developed specifically for reduced gravity have been partially validated within the constraints of the aircraft and ground facilities. However, typical flow ranges used for real water recovery systems require up to 2 to 3 minutes to fully develop. Testing on the ISS is required for complete validation of the semi-empirical models.

Science requirements in brief.-A Packed Bed Reactor Experiment (PBRE) is planned for flight on ISS in 2008. The experiment consists of several packed beds. Two of the beds are designated as the Fundamental Hydrodynamics Study (FHS) reactors. The purpose of these reactors will be to produce a full understanding of the packed bed hydrodynamics embodied by the generation of design guidelines and correlations for designing and sizing a packed column for a particular application. Two beds will be tested with wetting and non-wetting packing materials. Next, a hydrodynamic simulation of the Volatile Removal Assembly (VRA) packed bed will be tested under standard temperature and pressure. The actual VRA operates at $130 \mathrm{C}$ and $450 \mathrm{kPa}$. Finally, three beds will simulate the hydrodynamics for a Biological Water Processor (BWP). These beds will use a material such as BioBale ${ }^{\mathrm{TM}}$ with varying degrees of porosity to simulate biological growth. Increases in pressure drop and the distribution and retention of the gas phase will be carefully monitored.

TABLE 2.-CANDIDATE PACKED BEDS AND THEIR CHARACTERISTICS

\begin{tabular}{|c|c|c|c|c|}
\hline Bed & $\begin{array}{c}\text { ID } \\
\text { in }(\mathrm{cm})\end{array}$ & $\begin{array}{l}\text { Length } \\
\text { in }(\mathrm{cm})\end{array}$ & $\begin{array}{c}\text { Packing } \\
\text { Size } \\
\text { in }(\mathrm{cm}) \\
\end{array}$ & $\begin{array}{l}\text { Packing } \\
\text { Material }\end{array}$ \\
\hline FHS-W & $\begin{array}{c}2.5 \\
(6.4)\end{array}$ & $24(70)$ & $\begin{array}{c}0.079 \\
(0.2)\end{array}$ & $\begin{array}{c}\text { Glass } \\
\text { (spheres) }\end{array}$ \\
\hline $\begin{array}{l}\text { FHS- } \\
\text { NW }\end{array}$ & $\begin{array}{c}2.5 \\
(6.4)\end{array}$ & $24(70)$ & $\begin{array}{c}0.079 \\
(0.2)\end{array}$ & $\begin{array}{l}\text { Teflon } \\
\text { (spheres) }\end{array}$ \\
\hline VRA & $\begin{array}{c}1.4 \\
(3.6) \\
\end{array}$ & $\begin{array}{c}20 \\
(51) \\
\end{array}$ & $\begin{array}{c}0.065 \\
(0.165)\end{array}$ & $\begin{array}{c}\text { Glass } \\
\text { (spheres) }\end{array}$ \\
\hline BWP-1 & $\begin{array}{c}2.0 \\
(5.1)\end{array}$ & $\begin{array}{c}5 \\
(12.7)\end{array}$ & NA & $\begin{array}{l}\text { Bio Bale }{ }^{\mathrm{TM}}- \\
0 \% \text { simulated } \\
\quad \text { growth }\end{array}$ \\
\hline BWP-2 & $\begin{array}{c}2.0 \\
(5.1)\end{array}$ & $\begin{array}{c}5 \\
(12.7)\end{array}$ & NA & $\begin{array}{l}\text { Bio Bale } \text { BM }^{\mathrm{TM}}- \\
50 \% \text { simulated } \\
\text { growth }\end{array}$ \\
\hline BWP-3 & $\begin{array}{c}2.0 \\
(5.1)\end{array}$ & $\begin{array}{c}5 \\
(12.7)\end{array}$ & NA & $\begin{array}{l}\text { Bio Bale }^{\mathrm{TM}}- \\
80 \% \text { simulated } \\
\text { growth }\end{array}$ \\
\hline \multicolumn{2}{|c|}{ Tolerances on: } & \multicolumn{3}{|c|}{$\begin{array}{l}x= \pm 0.1 \text { inches }(0.254 \mathrm{~cm}) \\
x . x= \pm 0.03 \text { inches }(0.076 \mathrm{~cm}) \\
x . x x x= \pm 0.001 \text { inches }(0.00254 \mathrm{~cm})\end{array}$} \\
\hline
\end{tabular}

Flow rate requirements.-The flow rates required for the PBRE vary depending on the particular bed considered. For the FHS, since we planning to study the hydrodynamics over a wide range of flow rates, the variations required in mass flows are the greatest. For VRA on the contrary, the flow rates are very small as adjusted for ambient temperature and pressure. Table 3 shows the range of the gas flow rates for the different beds, and Table 4 shows the liquid flow rates.

TABLE 3.-MASS FLOW RATE REQUIREMENTS
\begin{tabular}{|l|c|c|c|c|}
\hline OF THE DISPERSED PHASE FOR THE PBRE \\
\hline Bed & $\begin{array}{c}\text { Minimum } \\
(\mathrm{kg} / \mathrm{hr})\end{array}$ & $\begin{array}{c}\text { Maximum } \\
(\mathrm{kg} / \mathrm{hr})\end{array}$ & $\begin{array}{c}\text { Maximum } \\
\text { increments between } \\
\text { set points } \\
(\mathrm{kg} / \mathrm{hr})\end{array}$ & $\begin{array}{c}\text { Control } \\
( \pm \mathrm{kg} / \mathrm{hr})\end{array}$ \\
\hline FHS & 0.05 & 5 & 0.05 for $<1 \mathrm{~kg} / \mathrm{hr}$ & 0.05 for $<1 \mathrm{~kg} / \mathrm{hr}$ \\
\hline VRA $^{[1]}$ & 0.0006 & 0.003 & 0.1 for $>1 \mathrm{~kg} / \mathrm{hr}$ & 0.1 for $>1 \mathrm{~kg} / \mathrm{hr}$ \\
\hline & & & 0.0003 & 0.0003 \\
BWP & 0.001 & 0.5 & $\begin{array}{c}0.01 \text { for } 0.01 \text { to } 0.1 \\
\mathrm{~kg} / \mathrm{hr}\end{array}$ & $\begin{array}{c}0.01 \text { for } 0.01 \mathrm{hr} 0.1 \\
\mathrm{~kg} / \mathrm{hr} \\
\mathrm{kg} / \mathrm{hr}\end{array}$ \\
& & & 0.1 for $>0.1 \mathrm{~kg} / \mathrm{hr}$ & 0.1 for $>0.1 \mathrm{~kg} / \mathrm{hr}$ \\
\hline
\end{tabular}

TABLE 4.-VOLUMETRIC FLOW RATE REQUIREMENTS OF THE LIQUID PHASE FOR THE PBRE

\begin{tabular}{|l|c|c|c|}
\hline Bed & $\begin{array}{c}\text { Minimum } \\
\text { flow rate } \\
\text { (liters/hr) }\end{array}$ & $\begin{array}{c}\text { Maximum } \\
\text { flow rate } \\
\text { (liters/hr) }\end{array}$ & $\begin{array}{c}\text { Control } \\
( \pm \text { liter } / \mathrm{hr})\end{array}$ \\
\hline FHS & 10 & 200 & 1 \\
\hline VRA & 4 & 10 & 0.5 \\
\hline BWP & 1 & 20 & 0.5 \\
\hline
\end{tabular}

The requirements also address the accuracy of measurements, the thermal and pressure control and the microgravity environment. Moreover, the phase distribution will be measured using tomography techniques throughout the column as well as liquid film thickness measurements which will be achieved using tiny impedance probes embedded into the packing pellets.

In the PBRE, the packed bed hydrodynamics will be evaluated without the drawbacks of the NASA's low gravity platform limitations. The pressure drop data outcomes will further improve the development of the pressure drop model because the low gravity time limitation is not an issue any longer and thereby, steady flows will be more readily 
achievable. Moreover, the hydrodynamics results will further define the flow map regimes and flow transitions. The BWP and VRA results will further impact the performance characteristics of the corresponding packed beds. Overall, the PBRE results will provide to designers design correlation for pressure drop and flow regimes that can be used to design packed beds for advanced life support.

\section{Conclusion}

We addressed in this paper the latest development in packed bed hydrodynamics and the findings related to the hydrodynamics of packed bed and the future plans for developing the current findings into more accurate correlations for packed bed designers for long duration space missions. We summarized in this paper the low gravity platform findings connected with two-phase friction factor, although flow maps and transition predictions have been addressed in great details by Motil et al. 2003. Then, we presented the plans for a Packed Bed Flight Experiment PBRE with the objective to generate hydrodynamics design correlations and performance data for the design and sizing of future low or microgravity packed beds.

\section{References}

Gianetto, A.; Baldi, G.; Specchia, V.; Sicardi, S., "Hydrodynamics and Solid-Liquid Contacting Effectiveness in Trickle-Bed Reactors," AIChE J., 24 [6] (1978) 1087-1104.

Kaviany, M., Principles of Heat Transfer in Porous Media, 2nd edition, Springer-Verlag, New York, 1995.

Motil, B.J., Balakotaiah, V., and Kamotani, Y., "Gas-Liquid TwoPhase Flows Through Packed Beds in Microgravity," AIChE J., 49 [3] (2003) 557-565.

Reiss, L.P.; "Cocurrent Gas-Liquid Contacting in Packed Columns," Ind. Eng. Chem. Process Des. Dev., 6 [4] (1967) 486-499.

Tosun, G., "A Study of Cocurrent Downflow of Nonfoaming GasLiquid Systems in a Packed Bed. 1. Flow Regimes: Search for a Generalized Flow Map 2. Pressure Drop: Search for a Correlation," Ind. Eng. Chem. Process Des. Dev., 23 (1984) 29-39. 


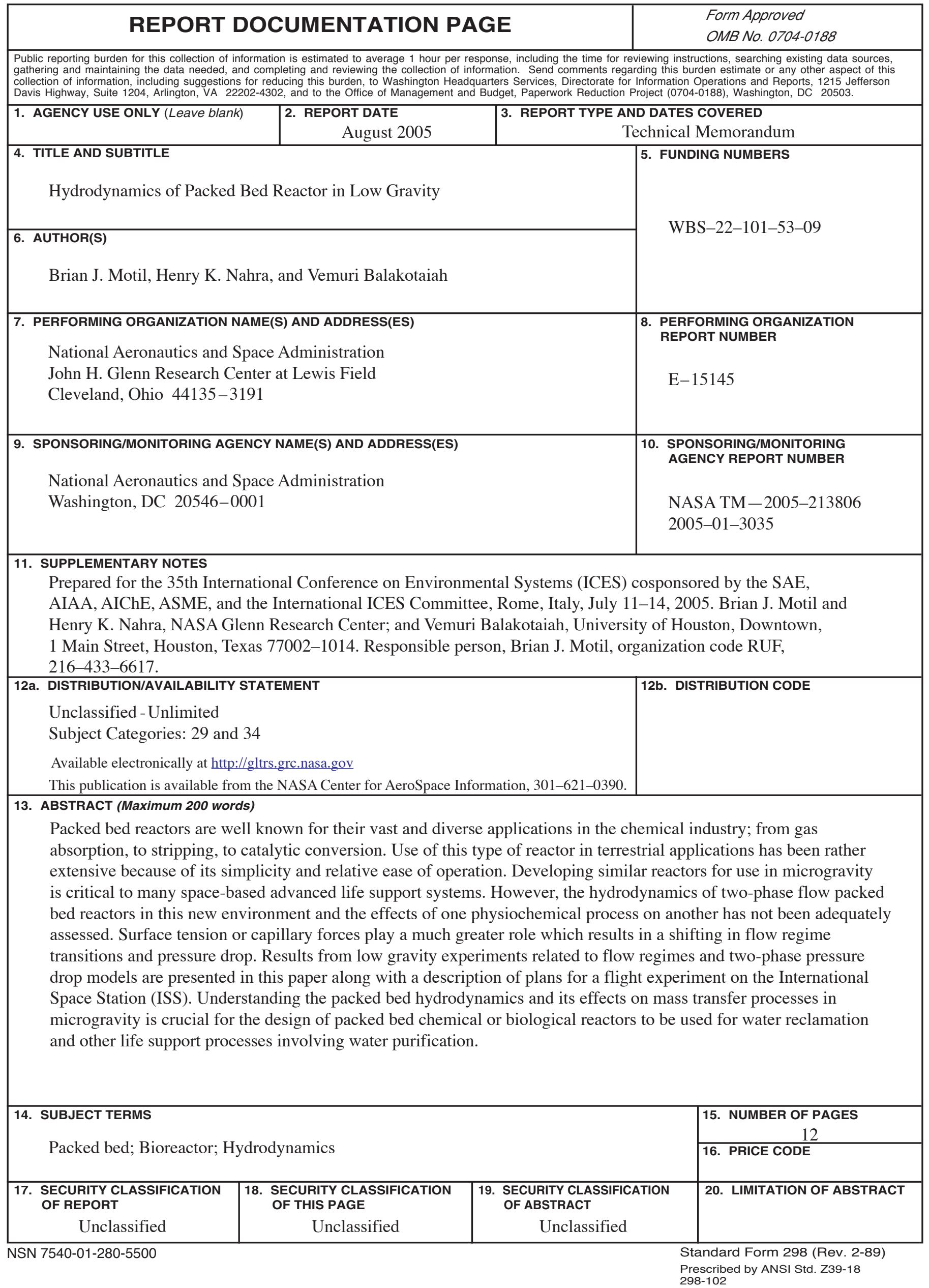



